\title{
Effect analysis of the different channel length and depth of photovoltaic thermal system with $\nabla$-groove collector
}

\author{
Saprizal Hadisaputra ${ }^{1}$, Muhammad Zohri ${ }^{2}$, Bahtiar $^{3}$, Ahmad Fudholi ${ }^{4}$ \\ ${ }^{1}$ Faculty of Science and Education, University of Mataram, Indonesia \\ ${ }^{2,3}$ Department of Physic Education, Universitas Islam Negeri (UIN) Mataram, Indonesia \\ ${ }^{2,4}$ Solar Energy Research Institute, Universiti Kebangsaan Malaysia, Malaysia
}

\begin{tabular}{l} 
Article Info \\
\hline Article history: \\
Received May 8, 2019 \\
Revised Oct 1, 2019 \\
Accepted Oct 17, 2019 \\
\hline Keywords: \\
Depth \\
Electrical \\
Length \\
Mathematical model \\
Thermal
\end{tabular}

\begin{abstract}
The converted Solar energy as electrical and thermal energy was named photovoltaic thermal (PVT). The aim of this study is to the analysis of different length and depth channel effect of photovoltaic thermal with $\nabla$-groove collector by a mathematical model. The matrix inversion was used to analyze the energy balance equation. Simulation results were conducted below the solar intensity of $800 \mathrm{~W} / \mathrm{m}^{2}$ and mass flow rate between 0.0069 $\mathrm{kg} / \mathrm{s}$ and $0.0491 \mathrm{~kg} / \mathrm{s}$. Electrical and thermal efficiency was done to assess the effect of different length and channel depth of PVT system with $\nabla$-groove collector. The effect of different length and depth of $\nabla$-groove collector for electrical and thermal performance is caused by changed mass flow rate. The effect Increasing of the mass flow rate of collector increased the thermal and electrical performance of the $\nabla$-groove collector.
\end{abstract}

Copyright (c) 2020 Institute of Advanced Engineering and Science. All rights reserved.

Corresponding Author:

Muhammad Zohri,

Department of physic education,

Universitas Islam Negeri (UIN) Mataram,

Indonesia.

Email: zohri.ukm@gmail.com

\section{INTRODUCTION}

Solar energy is one of renewable energy which has characteristic sanitary and harmless and sustainable. The conversion of solar energy to thermal and electrical energy is called Photovoltaic thermal (PVT) system. The PVT system is a combination of photovoltaic and solar collector technology. The over heat from PV panel is removed by air as medium cooling [1]. The performance of PVT system is excessive total energy transformation efficiency. The enactment and financial effectiveness of PVT system be contingent of numerous scheme parameters for example collector design shape, collector dimension, collector penetration, amount of collectors, Photovoltaic module form, glazed and unglazed collector, focused solar intensity [2].

Many studies of the photovoltaic thermal system with collector have been done by The theoretical and experimental assessment in last decades. Zohri et al. [3] have developed mathematical modeling of photovoltaic thermal with v-groove. The electrical and thermal efficiency have been compared with other design collectors. The use of v-groove was the higher efficiency than other design collectors. Zohri et al. [4] have done energy and exergy analyses of photovoltaic thermal with fins collector with theoretical approach. The use of fins collector is higher energy and exergy efficiency than without fins collector. Zohri et al. [5] have done developed performances analysis of photovoltaic thermal with and without fins collector. The energy performance of fins collector was very good than without fins collector. The theoretical approach or mathematical model of photovoltaic thermal with and without v-groove collector have been conducted by Zohri et al. [6]. the exergy performance results showed that using of v-groove collector be able to increase the exergy efficiency. 
Kumari and Babu [7] have analyzed the photovoltaic cell using the Matlab-Simulink situation with theoretical study. The objective of this study was to the discovery of nonlinear I-V equation. The best of I-V equation for the single-diode photovoltaic model counting the effect of the sequence and similar confrontations was found. Aminullah et al. [8] have conducted the influence analysis of solar intensity and combination of photovoltaic generator to power quality. The yield of dual adjusted passive sieve able to increase voltage and current THD grid. Sharma et al. [9] have done the modeling and representing analysis of off-grid control cohort system with photovoltaic. Mohammad et al. [10] have done theoretical approach of photovoltaic collection by application of fuzzy logic.

Many researchers just have conducted a thermal and electrical analysis of the PVT system with channel depth and length of collector constantly. The assessment with differences in length and a channel depth of collectors is still very rare in determining the achievement of the PVT system. In this simulation, a mathematical model for calculating the performance of the PVT system with $\nabla$-groove collector is calculated by variation of length and channel depth collector. Mathematical modeling is carried out to develop thermal and electrical efficiency using a steady-state condition. The $\nabla$-groove collector is a combination of $\mathrm{V}$-groove and plat plate collector. The process heat removals improved thermal efficiency because of the extended surface of absorber collector. The purpose of this study is to determine the best of length and depth of collector before to do the experimental investigation.

\section{THEORETICAL ANALYSIS}

The cross sectional view of the PVT with $\nabla$-collector is shown in our paper [11]. It shows various heat transfer coefficients. In order to write the energy balance equation of PVT system with $\nabla$-collector, the following assumptions are made as showed our in paper [12]. The steady-state equation of photovoltaic thermal with $\nabla$-groove collector as following

For module PV:

$$
\tau \alpha S-U_{t}\left(T_{p v}-T_{a}\right)-h_{c 1}\left(T_{p v}-T_{f}\right)=h_{r}\left(T_{p v}-T_{b}\right)+S \eta_{p v}+Q_{\nabla}
$$

The channel of air:

$$
\dot{m} C\left(T_{o}-T_{i}\right)-h_{c 1}\left(T_{p v}-T_{f}\right)=h_{c 2}\left(T_{b}-T_{f}\right)+Q_{\nabla}
$$

The bottom plate:

$$
h_{r}\left(T_{p v}-T_{b}\right)-U_{b}\left(T_{b}-T_{a}\right)=h_{c 2}\left(T_{b}-T_{f}\right)
$$

The photovoltaic thermal with $\nabla$-groove collector uses the matrix $3 \times 3$ for calculating the module PV temperature $T_{p v}$, the air temperature $T_{f}$, and bottom plate $T_{b}$ using inverse matrix as following. The completion of PVT system with $\nabla$-groove as following,

$$
\left[\begin{array}{ccc}
\left(U_{t}+h_{c 1}+Q_{\nabla}+h_{r}\right) & -h_{c 1}+Q_{\nabla} & -h_{r} \\
h_{c 1}+Q_{\nabla} & -\left(h_{c 1}+h_{c 2}+Q_{\nabla}+\dot{m} C\right) & h_{c 2} \\
h_{r} & h_{c 2} & -\left(h_{r}+h_{c 2}+U_{b}\right)
\end{array}\right]\left[\begin{array}{c}
T_{p v} \\
T_{f} \\
T_{b}
\end{array}\right]=\left[\begin{array}{c}
U_{t} T_{a}+\tau \alpha\left(1-\eta_{p v}\right) S \\
-2 \dot{m} C T_{i} \\
-U_{b} T_{a}
\end{array}\right]
$$

Where,

$$
\begin{aligned}
& Q_{\nabla}=N A n h_{c} \eta_{\nabla}\left(T_{p v}-T_{f}\right) \\
& \eta_{\nabla}=\operatorname{tanhMH} / M H \\
& M=\left(2 h_{c} l / k A_{c n}\right)^{0.5} \\
& h_{c 1}=h_{c 2}=h_{c} \\
& U_{b}=\frac{k_{t}}{l_{t}} \\
& U_{t}=\left(\frac{1}{h_{w}+h_{r p a}}\right)
\end{aligned}
$$

The settlement procedure uses the iteration process. The excel program is used to calculate all the heat transfer coefficients required in the mathematical model. The heat transfer characteristics are calculated according to the initial estimation of temperature values. In this study, inlet air temperature, ambient temperature, PV panel temperature and bottom plate temperature are predicted first. For PV panel temperature is set at $30{ }^{\circ} \mathrm{C}$ above ambient temperature. For the bottom plate temperature and the air 
temperature is set at $20{ }^{\circ} \mathrm{C}$ and $10{ }^{\circ} \mathrm{C}$ above the ambient temperature. The design parameters are $\mathrm{L}=2.4 \mathrm{~m}$, $\mathrm{W}=0.53, \alpha=0.9, \tau=0.92, \varepsilon_{p v}=0.7, \varepsilon_{b}=0.9, T_{a}=27, \mathrm{~T}_{\mathrm{i}}=27^{\circ} \mathrm{C}$.

The thermal energy efficiency of PVT system is given as [13-17]

$$
\eta_{\text {thermal }}=\frac{\dot{m} C\left(T_{o}-T_{i}\right)}{A S}
$$

Where, the area of collector is A, the specific heat of air is $C$, mass flow rate is $\dot{m}$, solar intensity is $S$, and the inlet and outlet temperature of air are $T_{i}, T_{o}$ respectively.

The electrical efficiency is calculated as [18]

$$
\eta_{p v}=\eta_{0}\left[1-0.0045\left(T_{p v}\right)\right]
$$

The heat transfer coefficient according to Ong [19] is

$$
h_{w}=2.8+3.3 \mathrm{~V}
$$

Where, $h_{w}$ heat transfer coefficient due to wind and $V$ is the wind velocity. The heat transfer coefficient from panel cell to sky

$$
\begin{aligned}
& h_{r, p v s}=\varepsilon_{p v} \sigma\left(T_{p v}^{2}+T_{s k y}^{2}\right)\left(T_{p v}-T_{s k y}\right) \\
& h_{r, p v b}=\frac{\sigma\left(T_{v p}+T_{b}\right)\left(T_{p v}^{2}+T_{b}^{2}\right)}{\left(\frac{1}{\varepsilon_{p v}}+\frac{1}{\varepsilon_{b}}-1\right)}
\end{aligned}
$$

Where $T_{s}$ is the sky temperature, $T_{p v}$ is the photovoltaic panel temperature.

$$
T_{\text {sky }}=0.0552 T_{a}^{1.5}
$$

Where, $\varepsilon_{p}, \sigma, T_{a}, T_{s k y}$, and $T_{p v}$ are the emissivity of panel Photovoltaic, Stefan Boltzman constant, ambient temperature, sky temperature and panel photovoltaic temperature, respectively

The convective heat transfer coefficients are calculated as follow [20]:

$$
h=\frac{k}{D_{h}} N u
$$

where,

$$
D_{h}=\frac{4 W d}{2(W+d)}
$$

Where, $W, D_{h}$ are the width, high equivalence diameter of the channel, $k$ is air thermal conductivity, and $N u$ is Nusselt number. Nusselt numbers are given as, for $\operatorname{Re}<2300$ (laminar flow region):

$$
N u=5.4+\frac{0.00190\left[\operatorname{RePr}\left(\frac{D_{h}}{L}\right)\right]^{1.71}}{1+0.00190\left[\operatorname{RePr}\left(\frac{D_{h}}{L}\right)\right]^{1.71}}
$$

For $2300<\operatorname{Re}<6000$ (transition flow region):

$$
N u=0.116\left(R e^{2 / 3}-125\right) \operatorname{Pr}^{1 / 3}\left[1+\left(\frac{D_{h}}{L}\right)^{2 / 3}\right]\left(\frac{\mu}{\mu_{w}}\right)^{0.14}
$$

For $\operatorname{Re}>6000$ (turbulent flow region):

$$
N u=0.018 \operatorname{Re}^{0.8} \operatorname{Pr}^{0.4}
$$


Where, $R e$ and $\operatorname{Pr}$ are the Reynolds and Prandtl number given as:

$$
\begin{aligned}
& R e=\frac{\dot{m} D_{h}}{A_{c h} \mu} \\
& \operatorname{Pr}=\frac{\mu C}{k}
\end{aligned}
$$

Specific heat

The physical properties of air are hypothetical vary linearly with temperature by Fudholi [21]:

$$
C=1.0057+0.000066(T-27)(21)
$$

Density,

$$
\rho=1.1774-0.00359(T-27)(22)
$$

Thermal conductivity

$$
k=0.02624+0.0000758(T-27)(23)
$$

Viscosity

$$
\mu=[1.983+0.00184(T-27)] 10-5(24)
$$

The theoretical model assumes that for a short collector or less of $10 \mathrm{~m}$. Then, the mean air temperature is then equal to the arithmetic mean, where:

$$
T_{f}=\frac{\left(T_{i}+T_{o}\right)}{2}
$$

\section{RESULTS AND DISCUSS}

In this simulation, the thermal and electrical performance of PVT with $\nabla$-groove has been predicted by the mathematical model. The yield of the mathematical model is assumed steady-state condition. The different solar radiation and mass flow rate caused different thermal and electrical performances. The simulation studies have been done with the influence of the different collector length $\mathrm{L}$ and channel depth d with mass flow rate from $0.0069 \mathrm{~kg} / \mathrm{s}$ to $0.0491 \mathrm{~kg} / \mathrm{s}$ and the solar intensity of $800 \mathrm{~W} / \mathrm{m}^{2}$. The collector length $\mathrm{L}$ determined with the distance of the air channel through the collector channel during the transfer process. Figure 1 shows the thermal efficiency versus mass flow rate with the different collector length $\mathrm{L}$. The optimum thermal efficiency is $39.05 \%$ at the mass flow rate of $0.0491 \mathrm{~kg} / \mathrm{s}$ with the length collector of $2.4 \mathrm{~m}$. The minimum thermal efficiency is $30.71 \%$ with the length collector of $6 \mathrm{~m}$. Generally, the thermal efficiency increases nonlinearly to the maximum and then decrease as the collector length increases.

Figure 2 shows the electrical efficiency versus the mass flow rate at the solar intensity of $800 \mathrm{~W} / \mathrm{m}^{2}$ with different collector length $L$. The electrical efficiency results were a non-linear reduction when the collector length $L$ increased. The optimum electrical efficiency is $10.43 \%$ with the collector length of $2.4 \mathrm{~m}$. and the minimum electrical efficiency is $10.22 \%$ with collector length of $6 \mathrm{~m}$. The decrease of electrical efficiency is due to the higher rise of photovoltaic panel temperature for lower mass flow rate when the collector length increases.

Figure 3 shows the mass flow rate versus thermal efficiency with different channel depth $d$ at the solar intensity of $800 \mathrm{~W} / \mathrm{m}^{2}$. The collector channel depth affects the heat transfer rate from collector to the airflow through it and consequently affects the performance of the PVT system. In this study, the collector depth is used from $0.04 \mathrm{~m}$ to $0.07 \mathrm{~m}$. The thermal efficiency in the collector channel depth of $0.04 \mathrm{~m}$ reaches about $41.89 \%$. When the collector channel depth is $0.05 \mathrm{~m}$, thermal efficiency decreases about $38.20 \%$. And subsequently decreased by about $32.70 \%$ when the collector channels depth is $0.07 \mathrm{~m}$.

Figure 4 shows electrical efficiency versus the mass flow rate with different channel depth $\mathrm{d}$ at the solar intensity of $800 \mathrm{~W} / \mathrm{m}^{2}$. The electrical efficiency of the PVT system changes when the channel depth $\mathrm{d}$ is also changed. Electrical efficiency with mass flow rate from $0.0069 \mathrm{~kg} / \mathrm{s}$ to $0.0491 \mathrm{~kg} / \mathrm{s}$ about is $10.50 \%$ at channel depth of $0.04 \mathrm{~m}$. When the channel depth is $0.05 \mathrm{~m}$, the electrical efficiency decrease about $10.40 \%$. and declining electrical efficiency is until $10.27 \%$ when the depth of the collector is $0.07 \mathrm{~m}$. The reduction in electrical efficiency of the collector is due to the temperature increase of photovoltaic panel because the channel depth $\mathrm{d}$ is improved 


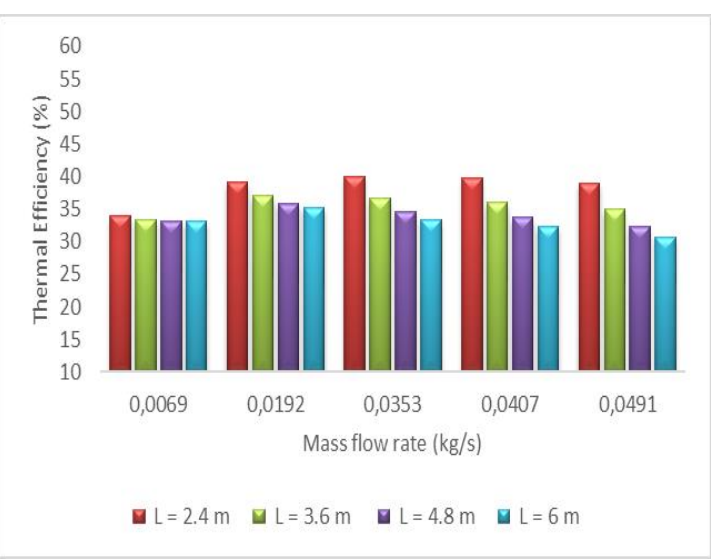

Figure 1. Thermal efficiency versus mass flow rate with different collector length $L(d=0.04 \mathrm{~m})$

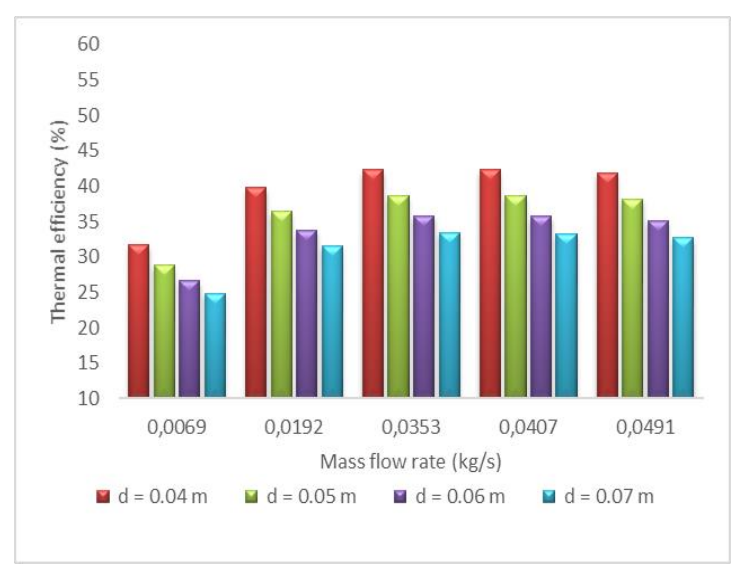

Figure 3. Mass flow rate versus thermal efficiency with different channel depth $\mathrm{d}(\mathrm{L}=2.4 \mathrm{~m})$

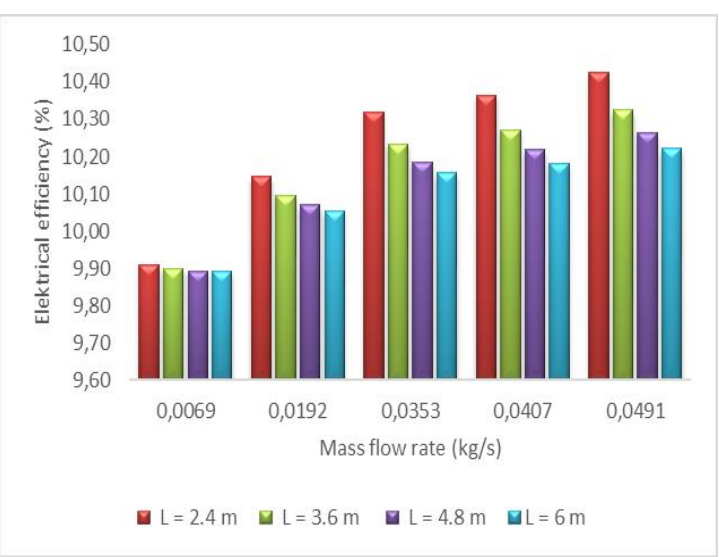

Figure 2. Electrical efficiency versus mass flow rate with different collector length $L(d=0.04 \mathrm{~m})$

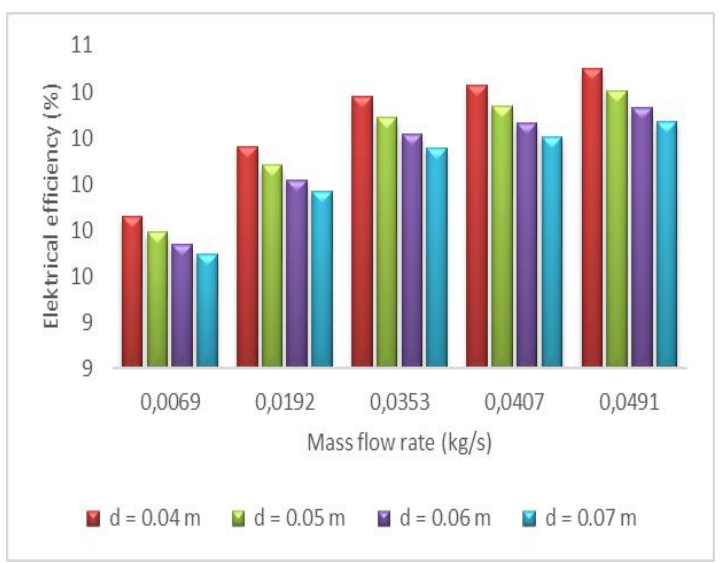

Figure 4. Electrical efficiency versus the mass flow rate with different channel depth $d(L=2.4 \mathrm{~m})$

In this study, the comparison of the results with preceding theoretical or experimental studies is valuable. Table 1 shows that the use of channel depth of $0.04 \mathrm{~m}$ or $0.05 \mathrm{~m}$ and length of $2.4 \mathrm{~m}$ produced higher thermal and electrical efficiency than increase channel depth and length of the collector. The yield of this simulation shows that this result very closed to the results by Abd-AlRaheem and Amori [22]. The change in the channel depth and length of collector have an important effect on the electrical and thermal efficiency. The Increasing of the mass flow rate of collector increased the thermal and electrical performance of the collector.

Table 1. The comparison with previous studies

\begin{tabular}{|c|c|c|c|}
\hline \multirow[t]{2}{*}{ References } & \multirow[t]{2}{*}{ Parameters } & \multicolumn{2}{|c|}{ Efficiencies } \\
\hline & & Thermal (\%) & Electrical (\%) \\
\hline Kasaeian et al. [23] & $\begin{array}{l}d=0.01-0.05 \mathrm{~m} \\
\dot{m}=0.018-0.06 \mathrm{~kg} / \mathrm{s}\end{array}$ & $15-31$ & $12-12.4$ \\
\hline Joshi et al. [24] & $\begin{array}{l}d=0.05 \mathrm{~m} \\
\dot{m}=0.05 \mathrm{~kg} / \mathrm{s}\end{array}$ & $13.4-16.5$ & $9.5-11$ \\
\hline Sarhaddi et al. [25] & $\begin{array}{l}d=0.05 \mathrm{~m} \\
\dot{m}=0.06 \mathrm{~kg} / \mathrm{s}\end{array}$ & 25 & 10 \\
\hline Kim et al. [26] & $d=0.06 \mathrm{~m}$ & 22 & 15 \\
\hline Tonui and Tripanagnostopoulos [27] & $\begin{array}{l}d=0.15 \mathrm{~m} \\
\dot{m}=0.05 \mathrm{~kg} / \mathrm{s}\end{array}$ & 18 & 12 \\
\hline Abd-AlRaheem and Amori [22] & $d=0.24 \mathrm{~m}$ & 50 & 10 \\
\hline Present study & $\begin{array}{l}d=0.04-0.07 \mathrm{~m} \\
\dot{m}=0.0069-0.0491 \mathrm{~kg} / \mathrm{s}\end{array}$ & $32.70-41.89$ & $10.50-10.27$ \\
\hline
\end{tabular}




\section{CONCLUSION}

The performances of electrical and thermal efficiency with $\nabla$-groove collector have been conducted by a mathematical model with the difference channel depth $\mathrm{d}$ and length $L$. Optimum thermal and electrical efficiency are $39.05 \%, 10.43 \%$ respectively with the collector length $L$ of $2.4 \mathrm{~m}$. The optimum thermal and electrical efficiency are $41.89 \%, 10.50 \%$ respectively with the collector depth $\mathrm{d}$ of $0.04 \mathrm{~m}$. The variation of the length and depth of the collector is effected by changed mass flow rate and solar intensity. The effect Increasing of the mass flow rate of collector increased the thermal and electrical performance of the collector. The best of mass flow rate, length, and depth of collector is $0.0491 \mathrm{~kg} / \mathrm{s}, 2.4 \mathrm{~m}$ and $0.04 \mathrm{~m}$, respectively.

\section{ACKNOWLEDGEMENTS}

The authors would like to thank the Solar Energy Research Institute (SERI), University Kebangsaan Malaysia. And this research was financially supported by Hibah KEMENRISTEKDIKTI Indonesia, and their support is gratefully acknowledged.

\section{REFERENCES}

[1] A. Fudholi, et al., "Heat transfer and efficiency of dual channel PVT air collector: a review," International Journal of Power Electronics and Drive System (IJPEDS), vol. 10(4), pp. 2037-2045, Dec. 2019.

[2] A. Fudholi, M. F. Musthafa, A. Ridwan, R.Yendra, Hartono, A.P.Desvina, M.K.B.M. Ali, K.Sopian, "Review of solar photovoltaic/thermal (PV/T) air collector," International Journal of Electrical and Computer Engineering (IJECE), vol. 1(1), pp. 126-133, 2019.

[3] M. Zohri, A. Fudholi, M. H. Ruslan, and K. Sopian, "Mathematical modeling of photovoltaic thermal PV/T system with v-groove collector," AIP Conference Proceedings, vol. 1862, pp. 030063-1, 2017.

[4] M. Zohri, S. Hadisaputra, A. Fudholi1, "Exergy And Energy Analysis Of Photovoltaic Thermal (PVT) With And Without Fins Collector," ARPN Journal of Engineering and Applied Sciences, vol. 13(3), pp. 803-808, 2018.

[5] M. Zohri, et al., "Photovoltaic-Thermal (PVT) System with and Without Fins Collector: Theoretical Approach," International Journal of Power Electronics and Drive System (IJPEDS), vol. 8(4), pp. 1756-1763, Dec. 2017.

[6] M. Zohri. Nurato, L. D. Bakti, A. Fudholi, "Exergy Assessment of Photovoltaic Thermal with V-groove Collector Using Theoretical study," TELKOMNIKA (Telecommunication, Computing, Electronics and Control), vol. 16(2), pp. 550-557, Apr. 2018.

[7] J. S. Kumari and Ch. S. Babu, "Mathematical modeling and simulation of photovoltaic cell using Matlab-simulink environment," International Journal of Electrical and Computer Engineering (IJECE), vol. 2(1), pp. 26-34, 2012.

[8] O. Amirullah, A. Penangsang, Soeprijanto, "Power Quality Analysis of Integration Photovoltaic Generator to Three Phase Grid under Variable Solar Irradiance Level," TELKOMNIKA (Telecommunication Computing Electronics and Control), vol. 14(1), pp. 29-38, 2016.

[9] H. Sharma, N. Pal, P.K. Sadhu, "Modeling and Simulation of Off-Grid Power Generation," TELKOMNIKA Indonesian Journal of Electrical Engineering, vol. 13(3), pp. 418- 424, 2015.

[10] N. Mohammad, M.A. Islam, T. Karim, Q.D. Hossain, "Improved solar photovoltaic array model with FLC based maximum power point tracking," International Journal of Electrical and Computer Engineering (IJECE), vol. 2(6), pp. 717-730, 2012.

[11] A. Fudholi, M. Zohri, G.L Jin, A. Ibrahim, C.H. Yen, M.Y. Othman, M.H. Ruslan, K. Sopian, "Energy and exergy analyses of photovoltaic thermal collector with $\nabla$-groove," Solar Energy, vol. 159, pp. 742-750, 2018.

[12] A. Fudholi, M. Zohri, N. S. B. Rukman, N.S. Nazri, M. Mustapha, C. H. Yen, M. Mohammad, K. Sopian, "Exergy and sustainability index of photovoltaic thermal (PVT) air collector: A theoretical and experimental study," Renewable and Sustainable Energy Reviews, vol. 100, pp. 44-51, 2019.

[13] R. K. Agarwal and H. P. Garg, "Study of a Photovoltaic Thermal System Thermosyphonic Solar Water Heater Combined With Solar Cells," Energy Convers. Manag., vol. 35(7), pp. 605-620, 1994.

[14] A. Fudholi, et al., "Performance and Cost Benefits Analysis of Double-Pass Solar Collector With and Without Fins," Energy Conversion and Management, vol. 76, pp. 8-19, 2013.

[15] A. Fudholi, et al., "Collector Efficiency of the Double-Pass Solar Air Collectors With Fins," Proceedings of the 9th WSEAS International Conference on System Science and Simulation in Engineering (ICOSSSE'10), Japan, pp. 428-34, 2010.

[16] A. Fudholi, et al., "Experimental Study of the Double-Pass Solar Air Collector With Staggered Fins," Proceedings of the $9^{\text {th }}$ WSEAS International Conference on System Science and Simulation in Engineering (ICOSSSE'10), Japan, pp. 410-14, 2010.

[17] A. Fudholi, et al., "Performance Analysis of Photovoltaic Thermal (PVT) Water Collectors," Energy Conversion and Management, vol. 78, pp. 641-651, 2014.

[18] R. J. Amrizal N, Chemisana D, "Hybrid photovoltaic-thermal solar collectors dynamic modeling," Appl Energy, vol. 101, pp. 797-807, 2013

[19] K. S. Ong, "Thermal performance of solar air heaters: Mathematical model and solution procedure," Sol. Energy, vol. 55(2), pp. 93-109, 1995.

[20] T. T. Chow, "A review on photovoltaic/thermal hybrid solar technology," Appl. Energy, vol. 87(2), pp. 365-379, 2010. 
[21] A. Fudholi, K. Sopian, M. Y. Othman, M. H. Ruslan, and B. Bakhtyar, "Energy analysis and improvement potential of finned double-pass solar collector," Energy Convers. Manag., vol. 75, pp. 234-240, 2013.

[22] M.A. Abd-AlRaheem and Amori, "Field study of various air based photovoltaic/thermal hybrid solar collectors," Renewable Energy, vol. 63, pp. 402-414, 2014.

[23] Kasaeian, Alibakhsh, Y. Khanjari, S. Golzari, O. Mahian, and S. Wongwises, "Effects of forced convection on the performance of a photovoltaic thermal system: An experimental study," Experimental Thermal and Fluid Science, vol. 85, pp. 13-21, 2017.

[24] A. Joshi, et al., "Performance evaluation of a hybrid photovoltaic thermal (PV/T) (glass-toglass) system," International Journal of Thermal Sciences, vol. 48(1), pp. 154-164, 2009.

[25] F. Sarhaddi, et al., "An improved thermal and electrical model for a solar photovoltaic thermal (PV/T) air collector," Applied Energy, vol. 87(7), pp. 2328-2339, 2010.

[26] Kim, J.-H., S.-H. Park, and J.-T. Kim, "Experimental Performance of a Photovoltaic-thermal Air Collector," Energy Procedia, vol. 48, pp. 888-894, 2014.

[27] J. K. Tonui and Y. Tripanagnostopoulos, "Performance improvement of PV/T solar collectors with natural air flow operation," Solar Energy, vol. 82, pp. 1-12, 2008.

\section{BIOGRAPHIES OF AUTHORS}

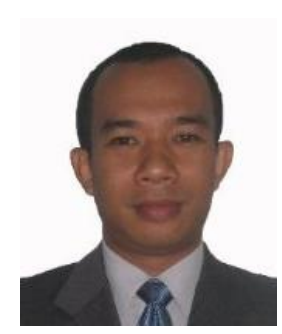

Saprizal Hadisaputra is currently a chemistry lecturer the University of Mataram, Lombok, Indonesia. His Ph.D degree was obtained in from Austrian-Indonesian Centre for Computational Chemistry, Universitas Gadjah Mada at 2014 in the field of Physical Chemistry/Computational Chemistry. He took his bachelor degree of chemistry at the same university and finished his master degree in Nanotechnology at Flinders University, Australia. He actively conducts research in computational chemistry that focuses on the use of quantum mechanics to predict the corrosion inhibition performance and energy storage of new materials. He published many articles in national and international journals.

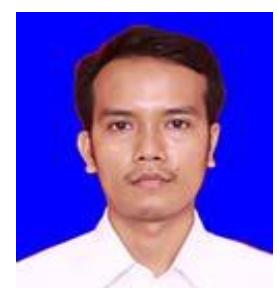

Muhammad Zohri obtained his S.Si (2009) in physics and received the Master of Science degree in Solar Energy Research Institute from The National University of Malaysia, Malaysia in 2017, with a thesis based on PVT system. He was appointed a Graduate Research Assistant (GRA) under Dr. Ahmad Fudholi in Solar Energy Research Institute (SERI) in UKM Malaysia, during his master's degree. He worked at State Islamic University (UIN) Mataram, Indonesia. He was a speaker at The 2nd International Symposium on Current Progress in Mathematics and Science (2nd ISCPMS) FMIPA UI in Depok and The 4th Solar Energy Research Institute (SERI) Colloquium 2016, in UKM Bangi, Malaysia. He has published many paper in Scopus and WoS Index.

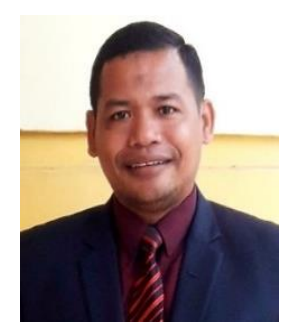

Bahtiar is currently a physic lecturer the State Islamic University (UIN) Mataram, Lombok, Indonesia. His Ph.D degree was obtained in from State University of Surabaya, Indonesia at 2016 in the field of Physic education. He took his Master degree of Physic education at State University of Yogyakarta. He actively conducts research in physic and physic education. He published many articles in national and international journals. He was a speaker at MathematicInformatics-Science-Education International-Conference (MISEIC) 2017, 2018 by FMIPA State University of Surabaya and international Conference on Environmental and Science Education (ICESE) 2019 by FMIPA State University of Semarang.

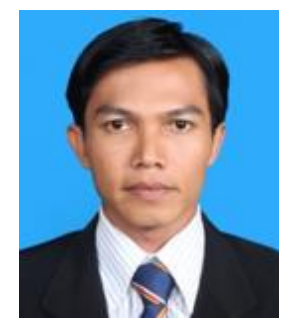

Ahmad Fudholi obtained his S.Si (2002) in physics. He has working experience about 4 years (2004-2008) as Head of Physics Department at Rab University Pekanbaru, Indonesia. A. Fudholi started his master course in Energy Technology (2005-2007) at UniversitiKebangsaan Malaysia (UKM). After his master he became Research Assistant at UKM up to 2012. After his Ph.D (2012) he became Postdoctoral in Solar Energy Research Institute (SERI) UKM up to 2013. He joined the SERI as a Lecture in 2014. More than USD 304,000 research grant in 2014-2017 obtained. More than $25 \mathrm{M} . \mathrm{Sc}$ project supervised and completed. Until now, he managed to supervise $6 \mathrm{Ph} . \mathrm{D}$ ( 4 main supervisor and 1 Co. supervisor), 2 Master's student by research mode, and 5 Master's student by coursework mode, he was also as examiner ( $3 \mathrm{Ph} . \mathrm{D}$ and $1 \mathrm{M}$.Sc). His current research focuses on renewable energy, especially energy technology. He has published more than 100 peer-reviewed papers, which 25 papers in ISI index (20 Q1, impact factor more than 3) and more than 48 papers in Scopus index, 10 more currently accepted manuscript, 20 more currently under review, and 2 book chapters. Addition, he has published more than 70 papers in international conferences. His total citations of 571 by 395 documents and h-index of 12 in Scopus (Author ID: 57195432490). His total citations of 1093 and h-index of 19 in google scholar. He is appointed as reviewer of high impact journal such as Renewable and Sustainable Energy Reviews, Energy Conversion and Management, Applied Energy, Energy and Buildings, 
Applied Thermal Engineering, Energy, Industrial Crops and Products, etc. He is appointed as reviewer of reputation journals such as Drying Technology, International Journal of Green Energy, Drying Technology, Bio system Engineering, Journal of Sustainability Science and Management, Journal of Energy Efficiency, Sains Malaysiana, Jurnal Teknologi etc. He is also appointed as editor journals. He has received several awards such as Gold Medal Award at the International Ibn Al-Haytham's Al-Manazir Innovation and Invention Exhibition 2011, Silver Medal Award at the International Technology EXPO (ITEX) 2012, Silver Medal Award at the Malaysia Technology Expo (MTE) 2013, Bronze Medal Award at International Exposition of Research and Invention (PECIPTA) 2011, also 2 Bronze Medal Award at PECIPTA 2017. He was also invited as speaker: Workshop of Scientific Journal Writing; Writing Scientific Papers Steps Towards Successful Publish in High Impact (Q1) Journals. 